\title{
Does Monetary Policy and Foreign Direct Investment Have an Influence on the Performance of Stock Market: Further Empirical Evidence From Ghana
}

\author{
Opoku Adabor (10 ${ }^{1}$ Emmanuel Buabeng (10) ${ }^{2}$
}

Received: 26.10.2020; Revised: 11.12.2020; Accepted: 13.12.2020

\begin{abstract}
Monetary policy, foreign direct investment and stock market continue to dominate in discussions in developing countries. However, the linkage between the three variables in empirical literature remains unclear. This study aims to test two separate hypotheses: Firstly, the study examines the effects of monetary policy on stock market performance in Ghana. Secondly, the study also empirically investigates the effect of foreign direct investment on stock market performance in Ghana. Autoregressive Distributed Lag (ARDL) model was employed as an estimation strategy to examine the short and long run effects using annual time series data from 1990 to 2019. The study revealed that monetary policy rate and money supply exerts a statistically significant negative and a positive effect on stock market performance in both long and short run in Ghana, respectively. It was also found that foreign direct investment has significant and a positive effect on stock market performance in Ghana in both the long and short run. Total capital stock and volume traded were also found to exert a significant positive and negative impacts on stock market performance both in the short and long run respectively. Based on our findings, we recommend that expansionary monetary policy will be a better option to be carried out to improve the stock market performance in Ghana. Furthermore, government and private partnership may ensure the effective management of the macroeconomic variables to attract foreign direct investment into Ghana to boost stock market performance.
\end{abstract}

JEL codes: E51, F10, C25

Keywords: Stock Market, Monetary Policy, Foreign Direct investment, ARDL, Ghana

\section{Introduction}

1 Department of Economics, KNUST, Kumasi, Ghana. (e-mail: adaboropoku@gmail.com).

2 Department of Economics, Kwame Nkrumah University of Science and Technology, Kumasi, Ghana. (e-mail: ebuabeng79@gmail.com)
The stock market is an essential component of the financial system which play a significant role in economic development of a country. Monetary policy on the other hand is a means by which the central banks 
of both developed and developing countries control money supply and credit in order to adjust interest with the main objective of significantly influencing economic activities of the country. The stock market plays an intermediary role between investors and firms to influence economic activities of a country (Muktadir-Al-Mukit, 2013). Monetary policy is part of the money market while the stock market is part of the capital market. Although the monetary policy and the stock market are two different markets, they are interlinked through several channels such as money supply and the monetary policy rate. The central bank of Ghana controls the stock market through monetary policy rate. Furthermore, they also control they the stock market through their control over money supply in the economy. Other macroeconomic variables such as interest rate and inflation also affect stock price which are transmitted by different economic policies (Durham, 2001). Hence the central bank controls monetary variables such as money supply, inflation and interest rate to influence the stock market performance. Several monetary policies have been adopted by the Central Bank of Ghana to maintain some level of stability in the financial market and also to boost economic activities. However, these policy regimes can be categorized into distinct categories, namely, the period associated with monetary controls and the period under which monetary policy has been allowed to develop in a setting of a liberalized environment.

The stock market is considered as one of the most vital areas of modern market economy as it provides deficit spending units (companies) in the economy with access to huge capital and gives surplus lending units (investors) in the economy with the opportunity to be part owners of these companies and receive returns on the basis of the future performance of these companies. Financial markets, including the stock market, serve as a catalyst for growth and economic development of countries. With this, Governments and policy makers around the world adopt numerous interventions and economic management policies such as monetary policy to regulate activities in the financial market to ensure economic stability.

Monetary policy on the other hand is a type of stabilization policy and as such it is usually adopted by central banks around the world to deal with imbalances in an economy. Keynes (1936) indicated that monetary policy plays a crucial role in the management and the general performance of an economy. He therefore asserted that changes in monetary variables such as money supply and interest rate will affect aggregate demand and return on financial assets in an economy. The real quantity of money demand relative to income is positively related to variation in stock prices, but negatively related to the contemporaneous stock market returns (M., 1988).

The mandated goal of monetary policy has been price stability and optimal output and employment in an economy. To achieve this goal, central banks can manipulate some monetary policy instruments, such as changing short-term interest rates and the volume of money supply through the broad channel of financial markets, including the stock market to influence the real economy. Thus, monetary policy affects investors' asset allocation decision making and this effect is subsequently transmitted into the real economy. Therefore, knowledge of the effect of monetary policy on financial market, and more specifically the stock market is crucial for policy makers and investors.

Ghana Stock Exchange was established in July, 1989 under Financial Sector Adjustment Programme (FINSAP). Comparatively, it has performed remarkably well in terms of returns on investment in its early years of operation. For instance, the market was adjudged the third best in emerging markets in 1992 in terms of capital appreciation. However, around the period 1995 
and 2005 the stock market in Ghana began to experienced a great deal of volatility and inconsistent performance due to the tight monetary policy stance of Bank of Ghana at that time which was aimed at stabilizing the Ghanaian economy (Antwi-Asare et al., 2010). From this period, the stock market began to gain it stability as the monetary authorities used money supply as means to achieve that. In 2010, the Central Bank shifted to the use of monetary policy rate to control the financial market. As a result, the stock market began to perform well from 2011. Although there have been rise in stock market performance in Ghana in recent years, there are still public outcries that unfavorable policies and market conditions such as high interest rate is affecting the performance of the stock market negatively (Taufian, 2018). The Ghana stock market plays a significant role in the economic development of every country through its intermediary role between investors and firms to influence economic activities. Through the stock market, firms are able to borrow to acquire new capital to expand their scale of production. Thus, significant proportion firms' investments are acquire through the stock market (Antwi-Asare et al., 2010). When firms expand their scale of production, it increases total output to promote economic. Expansion of firms' scale of production also calls for employment of new workers. This help to reduce unemployment and also increases income of workers. Increasing income of workers automatically increase their purchasing power which increase their standard of living.

Foreign direct investment (FDI) inflow from developed countries to developing countries has been seen as one of the significant factors that contribute to their growth and development. This so because foreign direct investment (FDI) inflow allows developing countries to develop it human capital base and also have access to modern technology to exploit it natural resources. FDI still remains the largest external source of finance for developing economies accounting for about $39 \%$ of total incoming finance in developing economies (UNCTAD, 2018). Thus making FDI an important fundamental parameter for economic growth and development as well as economic globalization. Furthermore, FDI is a significant factor which helps to bridge the gap between the developing and developed countries as well as serving as economic catalyst in fighting against poverty in developing countries. Another important contribution of foreign direct investment that has been overlooked is it potential ability to boost the stock market. Foreign direct investment serve as a major source technology, human capital and management transfer which influence the stock market. Foreign direct investment can also be in the form of direct purchases of stock or assets on the stock market which increases the performance of the stock market in Ghana. However, to ensure an effective and efficient direct flow of FDI to stock market, the health of the stock market must be strengthen through an effective organization and management (Raza, Ahmed, Ahmed, \& Ahmed, 2012).

Several empirical works have been devoted to examining empirical relationship between monetary policy and stock market in Ghana and other developing countries. For instance, Thorbecke (1997) in his study found a strong positive relationship between stock market returns and expansionary monetary policy in USA. Hayford and Malliaris (2004) in their study found a weak negative relationship between monetary policy and the stock market movements in some selected Asian countries. Sunday (2013) in his study, he found a positive relationship between monetary policy rate and stock market performance in Nigeria. Saleem et al. (2012) studied the impact of monetary policy on stock prices using annual time series data from 1985 to 2011 and VECM a negative relationship between contractionary monetary policy and stock market performance was found. In Ghana, few studies have 
been conducted on the impact of monetary policy on stock market movements. For instance Harvey, Liu, and Zhu (2015) used a quarterly times series data spanning the period 1991 to 2015 and a VECM model to study the relationship between monetary policy rate and stock market movements where a negative relationship was found between the two variables in Ghana. Again, using quarterly time's series data spanning 1993 to 2013 and 1991 to 2009 respectively and VAR model to study the relationship between monetary policy and stock market performance where positive relationship was found between the two variables in Ghana (Taufian, 2018; Antwi-Asare et al., 2010). These findings have produce inconclusive and varying results as some found a positive relationship between monetary policy and stock market development (Thorbecke, 1997; Sunday, 2013) and others also found a negative relationship between monetary policy and stock market development (Hayford \& Malliaris, 2004). It is therefore necessary to carry out this research using recent data and an appropriate method to re-examine the relationship between monetary policy and stock market performance in Ghana. This will help provide further empirical evidence to address the inconclusive results in empirical literature. In addition, much more needs to me learn about how foreign direct investment affect stock market performance since it limited in empirical literature in Ghana.

The rest of the paper is organized as follows: Related empirical literature was discussed in next section. Section three presents the data, the model, and the estimation strategy used in this paper. Econometric findings and diagnostic tests were presented in section four. Finally, section five concludes and provides some and policy recommendation.

\section{Related Empirical Literature}

Empirically, a several studies have examined monetary policy effect on stock market performance in developed and developing countries. Muktadir-Al-Mukit (2013) also examined effect of monetary policy variables on the performance of the stock market of Bangladesh using Granger causality as estimation strategy. The study also employed time series using monthly data over the period of 2006 to 2012 . The results from the study revealed that the existence of unidirectional causality from inflation, money supply and T-bill to market index.

Nwakoby and Alajekwu (2016) also examine effect of monetary policy on Nigerian stock market performance. The study used a time series data spanning 1986-2013 which was obtained from Central Bank of Nigeria. The study used ordinary least square and granger causality tests as estimation strategy and also Share Index as a proxy to measure stock market performance. Findings from the study revealed that monetary policy significantly explains $53 \%$ of changes stock market performances in Nigeria. Furthermore, the results from the granger causality tests had shown that causal relationship with lending and deposit rates in the long-run.

In a related study by (Durham, 2001) investigated effect of monetary policy on monthly and quarterly stock market returns employing panel cross regression as an estimation technique. The data used was a cross sectional data over the period of 1956 through 2000 for 16 countries. The study used the discount rate as the main policy instrument, which seem robust to alternative specifications of stock price returns. The study found out that there is a weaker and a diminished correlation between monetary policy changes and long-run stock market performance.

Osuagwu (2009) also investigated impact of monetary policy variables on the performance of the stock market in Nigeria. The study used ordinary least squares; cointegration and error-correction specification to estimate how monetary policy affects stock market performance. The study also used quarterly time series data starting from 
$1984-2007$. The study found out that stock market performance is strongly determined by broad money supply, exchange rates and consumer price index in the short and long-run.

Using ordinary least square as an estimation strategy, Ioannidis and Kontonikas (2006) investigated the effect of monetary policy on stock returns in thirteen OECD countries. The study used a cross-sectional data over the period 1972-2002. The results from the ordinary least square revealed that monetary policy shifts significantly affect stock returns.

In related study, Cassola and Morana (2004) employed the VAR methodology with real GDP, inflation, real M3 balances, short term interest rate, bond yield, and real stock prices as key variables in order to examine the transmission mechanism of monetary policy in the Euro area. The main aim of the study is to examine the impact of monetary policy on stock returns and stock prices. The study found out that a permanent positive monetary shock has a temporary positive effect on real stock prices.

Ioannidis and Kontonikas (2008) also did similar work on the impact of monetary policy on stock prices. The study used panel data from 1972 and 2002 of thirteen OCED countries on . monthly stock prices and interest rates. Estimates from the ordinary least squares and the Newey-West heteroscedasticity revealed that monetary policy shifts significantly affect stock returns. This confirms the notion of monetary policy transmission via the stock market.

Okpara (2010) also did an empirical study on monetary policy and stock market return in Nigeria. The study employed three different methodologies in analyzing the data. These include two stage least squared method, vector error correction model and the forecast error decomposition analysis. The findings from the study revealed that monetary policy is a significant affect stock market returns of Nigeria in the long-run. Specifically, high Treasury bill rate reduces stock market returns and thus, shows an evidence of monetary policy efforts to slow down the economy.

Using the vector error correction model as estimation strategy Yoshino et al. (2014) examined the reaction of Asian stock market prices to shocks of monetary policy changes, a case of the Tehran stock exchange. The study used time series data spanning 1970 to 2013. The study found out that stock prices continuously rise in reaction to exogenous monetary policy easing.

In a similar study, Nemaorani (2012) investigated the relationship between interest rate changes and securities returns in Botswana from 2001 to 201 . The study used ordinary least square method on real and nominal securities returns against short-term interest rates. The findings indicate that there is significant relationship between interest rate fluctuations and stock returns in both the long-run and short-run.

Employing vector autoregressive model (VAR) as an estimation technique, Ben Naceur and Kandil (2009) examine how Middle East and North African stock markets respond to monetary policy changes. The result from the VAR model shown that the securities prices were significantly and negatively affected in Jordan (the Middle East), Morocco and Tunisia (North Africa). Regarding Saudi Arabia and Oman, tight monetary policies were found to cause a decrease in securities prices.

Ngigi (2008) examined the effect of fiscal and monetary policies on stock market performance in Kenya. The study employed general to specific model specification and deduction method to estimate the variables. The results from the study revealed that expected monetary policy decisions and unanticipated fiscal policies decisions have a negative impact on securities market performance whereas unanticipated monetary policy decisions have a positive impact on securities market performance. On the other hand, anticipated fiscal policy was found to have no effect on stock market performance. 
Qayyum and Anwar (2011) also investigated the linkages between the monetary policy and the volatility of stock market in Pakistan using Engle Granger two step procedures and the bivariate EGARCH method estimation technique. The study used a time series data spanning from 1989 to 2010. They found out that any change in the monetary policy stance have a significant impact on the volatility of the stock market. In Ghana, Mwasya (2016) empirically investigated the effect of the monetary policy rate on stock market performance of firms listed on Ghana Stock Exchange. A Multiple Linear Regression Model was employed as estimation strategy with monthly data spanning from 1998 to 2015 . The results from the study revealed that monetary policy rate has negative effect on stock market performance in the long-run. The study also found that the inflation rate has a negative effect on stock market performance. Furthermore, Yao et al. (2011) examined the effect of fiscal and monetary policy actions on the stock market in Ghana using VAR model as a method to estimate all the variable used. The study employed quarterly time series data for Ghana between 1991 and 2006. The study found out that stock market activity is either enhanced or disrupted as a result of changes in any of the policy effects. Again, both from common correlation analysis to recent econometric modeling; indicate fiscal policy actions have significant effects on stock market activities and not the other way round. From the empirical review, monetary policy and stock market are linked through different policy variable. However, what is missing in empirical literature is to access the money supply and monetary policy rate channels through which monetary policy affect the stock market. Therefore this study has become necessary to fill the missing knowledge gab in empirical literature especially, in developing countries.

\section{Methodology}

This section presents a thorough discussion on the methods used by the study to achieve our objective. Firstly, we present the type and the source of data followed by the model specification and lastly the estimation strategy.

\subsection{Data type and source}

The study employed yearly time series data covering the period of 1990 to 2019 . The data was obtained from three different sources. Firstly, data on stock market capitalisation, capital and volumes traded was obtain from Ghana Stock Exchange. Furthermore, the second category of data on Monetary Policy Rate and Money Supply was obtained from the Bank of Ghana website. Lastly, data on foreign direct investment was obtained from world development indicator of the World Bank.

\subsection{Brief description of variables}

\section{Stock Market Capitalisation}

Stock capitalization can be defined as total value of all company's shares on the stock market. This variable is calculated as the aggregate of the product of the share price of each listed company on the stock exchange and its respective number of shares issued or outstanding at any point in time. For example, a publicly listed company trading on the stock exchange at a price of GH 05.00 per share and has 100,000,000 shares of common stock outstanding, will have a market capitalisation of GH $0500,000,000$. The market capitalisation of each individual company listed on the Ghana Stock Exchange is then aggregated into the Stock Market Capitalisation.

\section{Money Supply}

Money supply is basically defined as the quantity of currency or money in circulation in the public. The money supply composed of narrow to broad money. In a more simplified terms the money supply refers to the total deposit with the banks and the currency in the hands of the public. Money supply 
have influence on monetary policy rate. Increase in money supply increases money in the hands of individuals. This therefore implies that buying shares or trading on stock market increase or boost stock market performance. Hence the study expects positive relationship between money supply and stock market performance.

\section{Monetary Policy Rate}

The monetary policy rate is an interest rate at which the central bank can lends to the commercial banks. The Central Bank is the lender of last resort and hence lend money at this rate. The monetary policy rate is determined by the monetary policy committee at the central bank to ensure inflation target is always met due to changes in the economic variables. High monetary policy rate reduces the quantum money in circulation. This will reduce the purchase of shares on the stock market thereby reducing it performance. Hence the study expects a negative relationship between monetary policy and stock market performance.

\section{Volumes Traded}

Total value stock traded to GDP ratio shows the portion or fraction of the GDP made up by the total stock value traded on the stock market. The total value of stock traded ratio measures the organized trading of firm equity as a share of national output and therefore it should positively reflect liquidity on an economy as a whole. Liquidity in the stock market reduces the disincentive to investment as it provides more efficient resource allocation and hence economic development. Empirical literature have shown that total value of stock traded ratio is a better measure of stock market liquidity when taking into consideration the size of the economy as compared to the turnover ratio. (Levine and Zervos, 1996). The study expects a positive relationship between stock market performance and monetary policy.

\section{Capital}

Capital can be defined as money or wealth needed to produce goods and services for consumption. Gross fixed capital formation in this study was used as proxy $\mathrm{f}$ or capital stock. This variable was also employed by Fosu and Aryeetey (2008) in a study. The gross fixed capital formation is measured by fixed domestic assets less the part consumed in that yer and added to the non-produced assets (Baafi Antwi, 2010).

\section{Foreign Direct Investment}

Foreign direct investment is also defined as a category of cross border investment made by non-resident in the economy. It can also be defined as investment made by a firm or individual into business interests in another country. Foreign direct investment includes the sum total of value of reinvested earnings, value of affiliated equity and net intercompany loans (Alfaro \& Chauvin, 2012). The study expects positive relationship between foreign direct investment and stock market performance. Implying that inflow of investment and human capital to the domestic economy help boost stock market performance.

\subsection{Model specification}

To test the symmetric relationship between monetary policy rate and stock market performance of Ghana, the study followed previous empirical (Mwasya, 2016; Nemaorani, 2012) and general function and estimable model as below:

$$
S M C_{t}=f(M P, M 2, K, V T, F D I)
$$

Where $S M C$ is stock market capitalisation, $M P$ is monetary policy rate, $M 2$ is money supply, $K$ is capital, $V T$ is volumes traded and $F D I$ is foreign direct investment. The study followed the Cob-Douglas production log linear model to be able to transform equation (1) into an estimable linear form. This is shown below:

$$
\begin{gathered}
S M C_{t}=\beta_{0}\left(M P_{t}\right)^{\beta_{1}}\left(M 2_{t}\right)^{\beta_{2}}\left(K_{t}\right)^{\beta_{3}} \\
\left(V T_{t}\right)^{\beta_{4}}\left(F D I_{t}\right)^{\beta_{5}}+\left(e_{t}\right)^{\mu_{t}}
\end{gathered}
$$

The study took natural log of equation (2) to make it linear and estimable. Hence the general form is transformed to obtain an em- 
pirical form below;

$$
\begin{gathered}
\ln S M C_{t}=\beta_{0}+\beta_{1}\left(M P_{t}\right)+\beta_{2}\left(M 2_{t}\right)+ \\
\beta_{3}\left(K_{t}\right)+\beta_{4}\left(V T_{t}\right)+\beta_{5}\left(F D I_{t}\right)+\mu_{t}
\end{gathered}
$$

From equation (2), all the $\beta_{i}$ in the model were estimated. All the $\beta_{i}$ becomes elasticities since we have taken a natural of all the variables. Hence the coefficient could be interpreted as their long-run and short-run elasticities. For instance, $\beta_{2}$ which is coefficient of $\ln M 2_{t}$ can be explained as the elasticity $S M C_{t}$ of with respect to $M 2$. In particular, it measures the degree of responsiveness of $S M C$ to changes in money supply ceteris paribus. $\beta_{1}, \beta_{3}, \beta_{4}$ and $\beta_{5}$ represent their respective coefficient and elasticities and thus also show the same behaviour as $\beta_{2}$.

Through deduction from theoretical and past empirical studies, we hypothesize the following signs for our coefficients;

$\beta_{1}<0, \beta_{2}>0, \beta_{3}>0, \beta_{4}>0, \beta_{5}>0$

\subsection{Estimation strategy}

Several studies have employed the Johansen's cointegration estimation technique to examine the long run relationship between variables (see for instance Osuagwu, 2009; Nwakoby \& Alajekwu, 2016). However, Autoregressive Distributed Lag (ARDL) bounds test by the Pesaran and Pesaran (1997), Pesaran et al. (1999) and Pesaran et al. (2001) was introduced as an alternative cointegration estimation technique which has some advantages of over the former technique mentioned estimation strategy.

The ARDL approach is preferred over the former test because produce more reliable results as comparet to the former test when the sample size is relatively small (Ghatak $\&$ Siddiki, 2001). The former technique requires the use of only large sample size to be able to produce reliable results. Furthermore, the purpose behind the decision of the ARDL is that, $f$ or the previous system to be appropriate, the free factors must be coordinated in a similar request, yet this isn't vital f or the ARDL approach since factors can be incorporated in various requests however not past request 1 . This implies, the ARDL approach keeps away from the pre-testing issues related with standard co-incorporation, which necessitates that the factors as of now be grouped into I(1) or I(0) (Pesaran et al., 2001). Lastly, whereas the Vector Autoregressive Model (VAR) uses only endogeneous variables the ARDL approach is also applicable $f$ or both endogenous and exogenous variables together (Tang, 2006).

Pesaran and Pesaran (1997) asserted that to sepcify ARDL model, there is the need to conduct the bounds test to determine whether there is cointegration or not first before the specification can be done. This serves as a guide to determine the model to specify $f$ or the study. In addition,

The ARDL model works when the variables order of integration is mixed. Thus either integrated of order zero [i.e. $\mathrm{I}(0)]$ and oreder one [i.e. I(1)]. Any order of integration beyond 1 will not work $f$ or this ARDL model specification. This is pre-requisite $\mathrm{f}$ or the ARDL model. The model below is a general model specification of the ARDL test which includes both the long-run and shortrun terms, that is when the after conducting the bounds test and there exist cointegration. The ARDL bound test specifies the functional relationships between stock market capitalisation (SMC), money supply (M2), monetary policy rate (MP), volumes traded $(\mathrm{VT})$, capital $(\mathrm{K})$ and foreign direct invectment (FDI) is shown in equation (4). The ARDL model defines the dependent variable as a function of the lag of both the dependent variables and independent variables in both the short and long run. The model is define in the form ARDL $\left(p, q_{1}, q_{2}, q_{3}, q_{4}, q_{5}\right)$, where the " $p$ " refers to the optimal lag order of the independent variable and the "q" refers to the optimal lag order $f$ or the independent variables. In addition, the $\triangle$ is the first difference operator of the models. The parameters $\beta, \pi, \eta, \lambda$ and $\tau$ in the ARDL model represent the dynamic coefficient in 
the short-run while the long-run multipliers are denoted by $\delta_{1}$ to $\delta_{6}$, while $\epsilon_{t}$ is white noise error which is independent and identically distributed.

$$
\begin{gathered}
\triangle \ln S M C_{t}=\alpha_{0}+\sum_{t=1}^{p} \beta_{1} \triangle \ln _{S} M C_{t-1} \\
+\sum_{t=1}^{p} \pi_{1} \triangle \ln M 2_{t-1}+\sum_{t=1}^{p} \eta_{1} \triangle \ln F D I_{t-1} \\
+\sum_{t=1}^{p} \gamma_{1} \triangle M P_{t-1}+\sum_{t=1}^{p} \lambda_{1} \triangle V T_{t-1} \\
+\sum_{t=1}^{p} \tau_{1} \triangle K_{t-1}+\delta_{1} S M C_{t-1} \\
+\delta_{2} \ln M 2_{t-1}+\delta_{3} \ln F D I_{t-1}+\delta_{4} \ln M P_{t-1} \\
+\delta_{5} \ln V T_{t-1}+\delta_{6} \ln K_{t-1}+\epsilon_{t}
\end{gathered}
$$

The ARDL cointegration test is testing the following hypotheses:

$H_{0}=\delta_{1}=\delta_{2}=\delta_{3}=\delta_{4}=\delta_{5}=\delta_{6}=0$; (there is no cointegration. Thus, no long run relationship between the variables).

$H_{1} \neq \delta_{1} \neq \delta_{2} \neq \delta_{3} \neq \delta_{4} \neq \delta_{5} \neq \delta_{6} \neq 0$; (there is cointegration or long run relationship between the variables).

The above hypothesis is tested using the Fstatistic. It primarily tests for the hypothesis of no long-run relationship using the ARDL methodology. If the calculated F-stats is more than the upper critical value, the null hypothesis of no long-run relationship is rejected otherwise it is accepted. However, if the F-statistic lies between the lower and the upper bound, the result is not concluded. The error correction model cannot be overlooked when talking about ARDL model. It is used to estimate the speed of adjustment. The error correction model aims at reconciling the economic variables under consideration when there is a deviation from the short-run and long-run equilibrium. It simply measures the degree of deviation of the independent variables from equilibrium. The model is generated as;

$$
\begin{gathered}
\triangle Y_{t}=\alpha_{0}+\sum_{i=1}^{p} \beta_{i} \triangle Y_{t-i}+\sum_{i=1}^{q} \gamma_{i} \triangle X_{t-i} \\
+\delta E C M_{t-i}+\epsilon_{t}
\end{gathered}
$$

The $\mathrm{Y}$ in the model represents the dependent variable with its lags and $\mathrm{X}$ represents a list of independent variables with their lags, $\triangle$ denotes the first difference operator, whiles $\beta$ and $\gamma$ are the short run dynamic coefficients of the model. The $E C M_{t-i}$ is the error correction term and represent the long run which must have a negative sign and must be statistically significant with $\delta$ being its parameter indicating the speed of adjustment to long run equilibrium after a shock.

\subsection{Diagnostic test}

Finally, the study conducted a series of diagnostic test which include normality test, serial correlation test, heteroskedasticity test, functional test and the stability test. The normality and serial correlation test were done using the JarqueBera test and the Breusch- Godfrey LM test respectively, while Heteroskedasticity and functional test were conducted using Breusch-Pagan-Godfrey test and Ramsey reset test respectively. Regarding stability test, the study used the plots of CUSUM and CUSUMSQ.

\section{Empirical Results}

\subsection{Descriptive statistics of all the variabless}

Table 1 presents the descriptive statistics of the secondary data gathered on the six variables. The series have 28 observations representing the yearly time series from 1990 to 2019. While the mean shows the average of the series, the standard deviation indicates the deviation of the series from their mean values. Majority of the series show a little variation or deviation from the individual means except capital. The extent to which stock market capitalization, mon- 
etary policy, money supply, volume traded and foreign direct investment deviate from the individual means is not substantial except total capital. Stock market capitalization recorded an average of 3.2255 over the period of 1990 to 2018, while monetary policy recorded an average of 1.3601. The maximum value that stock market capitalization can attain is 4.8085 and its minimum value is 0.4712 , while the maximum value of monetary policy is 1.6532 and the minimum value is 1.0969 . Money supply also recorded an average of 3.2755 within the period 1990 to 2018 , while capital also had an average of 9.1384 within the same period. Money supply was found to have a maximum of 4.8206 and a minimum of 1.4698 while capital had a maximum of 10.5193 and a minimum of 7.4431. The results for volume traded and foreign direct investment have the same interpretations.

Table 1: Descriptive statistics of respondents

\begin{tabular}{lccccc}
\hline Var. & Obs. & Mean & S.D. & Min & Max \\
\hline $\operatorname{lnSMC}$ & 29 & 3.2255 & 1.4116 & 0.4712 & 4.8085 \\
$\operatorname{lnMP}$ & 29 & 1.3601 & 0.1705 & 1.0969 & 1.6532 \\
$\operatorname{lnM} 2$ & 29 & 3.2755 & 1.0392 & 1.4698 & 4.8206 \\
$\operatorname{lnK}$ & 29 & 9.1384 & 0.2593 & 7.4431 & 10.5193 \\
$\operatorname{lnVT}$ & 29 & 1.2132 & 0.2713 & 2.000 & 2.7146 \\
$\operatorname{lnFDI}$ & 29 & 1.9211 & 1.0241 & 1.8113 & 2.5310 \\
\hline
\end{tabular}

\subsection{Trend analysis of monetary policy rate, money supply and stock market performance}

From the Figure 1, Money Supply has a consistence increase in supply over the years. Within the period of 1990 to 2019 the money in circulation in the Ghanaian economy experienced a steady increase. The Stock Market Performance experience some shocks over the years yet still the consistent growth path was achieved. Monetary policy rate on the other hand started in 1990 at the highest point with the period under review and steadily declined but this decline was very small and relatively stable over time.

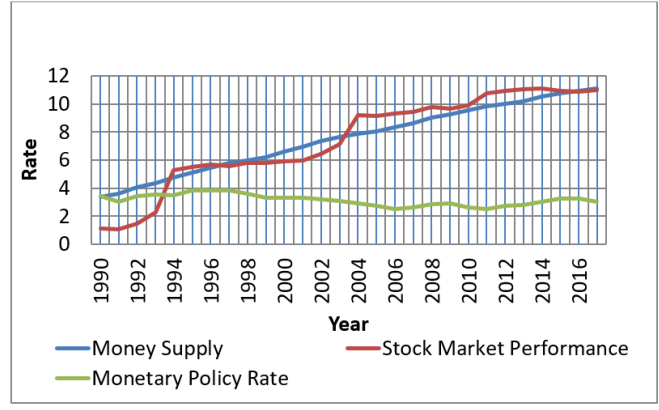

Figure 1: Trend Analysis

\subsection{Unit root test using the $A D F$ and PP method}

From the Table 2, the results of the stationarity test for $\mathrm{ADF}$ and $\mathrm{PP}$ shown that at Level only stock market capitalization, Volumes traded and Capital was statistically significant with only constant as well as constant and trend. Therefore, stock market capitalization, Capital and Volume traded attained stationarity at level. Regarding stationarity test at level first difference, monetary policy rate, money supply and foreign direct investment were significant with constant as well as constant and trend. Thus, monetary policy rate, money supply and foreign direct investment also attained stationarity at first difference. In view of this, it implies that monetary policy rate, money supply and foreign direct investment were all integrated of order one $\mathrm{I}(1)$ whiles stock market capitalization, Capital and Volume traded capitalization, Capital and Volume traded were integrated of order zero I $(0)$ series. Hence the study can apply the bounds test to examine the relationship between stock market performance and monetary policy in Ghana.

\subsection{ARDL Bounds Test Estimates}

The Table 3 present the results of the ARDL bounds test or cointegration results of the study. According to Table 3, the result of the bounds test shows that the Fstatistics of 29.5371 is greater than the upper bound. Since the F-statistics is greater than 
Table 2: Results of the stationarity test for ADF and PP

\begin{tabular}{|c|c|c|c|c|c|c|c|c|}
\hline \multirow[b]{3}{*}{ Variables } & \multicolumn{4}{|c|}{$\mathrm{ADF}$} & \multicolumn{4}{|c|}{ PP } \\
\hline & \multicolumn{2}{|c|}{ Levels } & \multicolumn{2}{|c|}{ 1st difference } & \multicolumn{2}{|c|}{ Levels } & \multicolumn{2}{|c|}{ 1st difference } \\
\hline & Constant & $\begin{array}{c}\text { Constant } \\
\text { with trend }\end{array}$ & Constant & $\begin{array}{l}\text { Constant } \\
\text { with trend }\end{array}$ & Constant & $\begin{array}{l}\text { Constant } \\
\text { with trend }\end{array}$ & Constant & $\begin{array}{l}\text { Constant } \\
\text { with trend }\end{array}$ \\
\hline $\operatorname{lnSMC}$ & $-2.398^{* *}$ & $-3.082^{* *}$ & $-3.322^{* *}$ & $-3.989^{* *}$ & $-2.108^{* *}$ & $3.011^{* *}$ & $-4.203^{* * *}$ & $-7.162^{* * *}$ \\
\hline $\operatorname{lnMP}$ & -1.392 & -1.604 & $-4.326^{* * *}$ & $-4.229^{* * *}$ & -2.014 & -1.105 & $3.204^{* * *}$ & $-3.115^{* *}$ \\
\hline $\operatorname{lnM} 2$ & -2.321 & -0.740 & $-2.381^{*}$ & $-3.482^{*}$ & -3.631 & 3.001 & $-1.022^{* * *}$ & $3.423^{* *}$ \\
\hline $\operatorname{lnFDI}$ & -2.313 & -2.648 & $-4.288^{* * *}$ & $-4.342^{* * *}$ & -2.325 & -2.581 & $-4.239^{* *}$ & $-4.315^{* *}$ \\
\hline $\ln K$ & $-3.618^{* *}$ & $-2.934^{* *}$ & $-3.184^{* *}$ & $-4.704^{* * *}$ & $-4.015^{* *}$ & $-4.086^{* *}$ & $-7.138^{* * *}$ & $-8.301^{* * *}$ \\
\hline $\operatorname{lnVT}$ & $-4.177^{*}$ & $-4.666^{* * *}$ & $-2.878^{* *}$ & $-3.805^{* *}$ & $-3.828^{* *}$ & $-4.506^{*}$ & $3.614^{* *}$ & $-6.903^{* *}$ \\
\hline
\end{tabular}

the upper bound at $5 \%$ significance level we can conclude there exist a long association or cointegration between Stock Market Performance and Monetary Policy in Ghana within the period under review.

Table 3: ARDL bounds test results for
cointegration relationship

\subsection{ARDL Long Run Estimates}

The Table 4 shows the result of the Long Run Estimates of the ARDL test of the study. From the Table 4, money supply has a p-value of 0.000 which indicates that Money supply has a significance effect on Stock Market Performance in the long-run in Ghana. The positive coefficient indicates that Money Supply has a positive significant effect on Stock Market Performance at $1 \%$ significance level in the long run. With all things being equal a $1 \%$ increase in Money Supply will lead to a $0.75 \%$ increase in Stock Market Performance in Ghana in the long run. Increase in money supply give room of individuals to purchase stocks on the stock market to boost market performance. When individuals hold more money, there are able to purchase more stocks to earn profit and this increase money supply in the long-run.

Regarding monetary policy rate it had a p- value of 0.000 which indicates that monetary policy has a significance impact on Stock Market Performance in the long run in Ghana. With a negative coefficient, the result suggests that monetary policy has a negative significant effect on Stock Market Performance at $1 \%$ significance level in the long run. With all things being equal a $1 \%$ increase in Stock monetary policy will lead to a $1.13 \%$ decrease in Stock Market Performance in Ghana in the long run. The implication of this result is that when the monetary policy rate increases money supply on the economy will fall and individuals are unable to purchase stocks on the stock market. This will decrease stock market performance in the long-run.

Capital has a p-value of 0.000 which indicates that capital has a significance impact on Stock Market Performance in the short run in Ghana. With a positive coefficient, the result suggests that capital has a positive significant effect on Stock Market Performance at $1 \%$ significance level in long run. With all things being equal a $1 \%$ increase in capital will lead to effect on Stock Market Performance at $1 \%$ significance level in long run.

Foreign direct investment has a p-value of 0.001 which indicates that foreign direct investment has a significance impact on Stock Market Performance in the long run in Ghana. With a positive coefficient, the result suggests that foreign direct investment has 
a positive significant effect on Stock Market Performance at $1 \%$ significance level in the long run. With all things being equal a $1 \%$ increase in foreign direct investment will lead to a $0.20 \%$ increase in Stock Market Performance in Ghana in the long run.

Stock volume traded has a p-value of 0.368 which indicates that Stock volume traded has no significance impact on Stock Market Performance in the long run in Ghana. With a negative coefficient, the result suggests that Stock volume traded has a negative insignificant effect on Stock Market Performance in the long run. With all things being equal a $1 \%$ increase in Stock volume traded will lead to a $0.12 \%$ decrease in Stock Market Performance in Ghana in the long-run.

Table 4: Estimated ARDL long run coefficients

\begin{tabular}{lcccc}
\hline Var. & Coef. & S.E. & t-Stat. & P \\
\hline LNM2 & 0.75208 & 0.097554 & 7.7094 & 0.040 \\
LNMP & -1.1333 & 0.11083 & -10.2248 & 0.001 \\
LNK & 1.0621 & 0.061676 & 17.2200 & 0.070 \\
LNFDI & 0.20419 & 0.050496 & 4.0437 & 0.011 \\
LNVT & -0.12012 & 0.13024 & -0.92233 & 0.368
\end{tabular}

\subsection{ARDL Short Run Estimates}

The Table 5 presents that results of the ARDL Short run estimates of the study. From the Table 5, Money Supply a significance positive effect on Stock Market Performance in the short run in Ghana. The positive significant suggests that Money Supply has a positive significant effect on Stock Market Performance at $5 \%$ significance level in the short run. Thus $1 \%$ increase in Money Supply will lead to a $0.33 \%$ increase in Stock Market Performance in Ghana in the short run all things being equal.

Regarding the control variables, monetary policy also raveled significance impact on Stock Market Performance in the short run in Ghana. The result suggests that monetary policy has a negative significant effect on Stock Market Performance at 1\% significance level in the short run. With all things being equal a $1 \%$ increase in monetary policy will lead to a $0.97 \%$ decrease in Stock Market Performance in Ghana in the short run.
Furthermore, capital has a p-value of 0.000 which indicates that Stock Turnover has a significance impact on Stock Market Performance in the short run in Ghana. With a positive coefficient, the result suggests that capital has a positive significant effect on Stock Market Performance at $1 \%$ significance level in short run. With all things being equal a $1 \%$ increase in capital will lead to a $0.98 \%$ increase in Stock Market Performance in Ghana in the short run. Also, Foreign direct investment also a significance impact on Stock Market Performance in the short run in Ghana. With a positive coefficient, the result suggests that foreign direct investment had a positive significant effect on Stock Market Performance at $1 \%$ significance level in the short run. With all things being equal a $1 \%$ increase in Capital will lead to a 0.09\% increase in Stock Market Performance in Ghana in the short run. Stock of volume traded also had a p-value of 0.352 which indicates that Monetary Policy Rate has no significance impact on Stock Market Performance in the short run in Ghana. With a negative coefficient, the result suggests that stock volume traded has a negative insignificant effect on Stock Market Performance in the short run. With all things being equal a $1 \%$ increase in Monetary Policy Rate will lead to a $0.05 \%$ decrease in Stock Market Performance in Ghana in the short run.

Lastly, the error correction model show that the error correction is highly statistically significant given that the coefficient and tstatistics is negative and also the p-value is below $1 \%$ hence the error correction model. The result of the error correcting model (ECM) indicates an adjustment to the equilibrium state after a shock. The lagged error term coefficient is negative $(-0.44281)$, as required and is strongly significant at $1 \%$ level. It also suggests that about $0.44 \%$ of distortions created by shocks in the preceding year can be restored in the current year. 
Table 5: Estimated ARDL short-run coefficients and the error correction estimate

\begin{tabular}{lcccc}
\hline Var. & Coef. & S.E. & t-Stat. & P \\
\hline $\operatorname{lnM} 2$ & 0.3330 & 0.12312 & 2.7049 & 0.013 \\
$\operatorname{lnMP}$ & -0.9737 & 0.0400 & -24.332 & 0.000 \\
$\operatorname{lnK}$ & 0.9840 & -0.0306 & 32.0943 & 0.000 \\
$\operatorname{lnFDI}$ & 0.09041 & 0.02067 & 4.3727 & 0.000 \\
$\operatorname{lnVT}$ & -0.0531 & 0.0558 & -0.9518 & 0.352 \\
ecm $(-1)$ & -0.44281 & 0.12915 & -3.4286 & 0.003 \\
\hline
\end{tabular}

4.7 Model Diagnostic and Reliability Test

The normality and serial correlation test was conducted using the Jarque-Bera test and the Breusch- Godfrey LM test respectively. Heteroskedasticity and functional test was done using Breusch-Pagan-Godfrey test and Ramsey reset test respectively. Finally, the stability of the model over the sample period is ascertained from the plots of CUSUM and CUSUMSQ.

From Table 6, it shows that ARDL model is free from econometric and statistical problems since all the probability values are greater than 0.05. Also the CUSUM and CUSUMQ graph in the appendix reveals that gross domestic product over the sample period is stable. This is because the plots of the Cumulative sum and Cumulative sum of square (CUSUM and CUSUMQ) lie within the 5 percent critical bound.

Table 6: Diagnostic and reliability test

\begin{tabular}{lcc}
\hline Diagnostic test & Test stat. & $\mathrm{P}$ \\
\hline Normality & 0.29426 & 0.9356 \\
Serial correlation & 0.96044 & 0.327 \\
Heteroskedasticity & 0.04897 & 0.825 \\
Functional form & 0.6639 & 0.426 \\
CUSUM & Stable & \\
CUSUMQ & Stable & \\
\hline
\end{tabular}

\section{Conclusions and policy recommenda- tions}

The main aimed of the study was to investigate into whether monetary policy had an effect on stock market performance in Ghana. The two main monetary policy variables used in the study were, Money Supply and Monetary Policy Rate. The study also did a Trend analysis on Money Supply and monetary policy rate in relation to stock market performance. The result from the cointegration test also indicated that, there exist a long run association or cointegration between the performance of the stock market and monetary policy in Ghana within the period under study. Regarding the main aims of the study, the results suggested that Money Supply had a positive significant effect on the performance of the stock market in both the short and long run in Ghana within the period 1990 to 2019. This however, means that when there in an increase in the money supply in the economy, we should expect the stock market to start performing as depicted in the trend analysis where the stock market is a lagging variable. Therefore, in the long run, the stock market performance depends significantly on quantity money supplied in the Ghanaian economy. Same conclusion is drawn for the short-run. The result from the ARDL model indicated that stock market performance was significantly influenced by money supply both in the short and long run. The influence was indicated to have a positive effect on stock market performance of Ghana. In view of this, the following recommendations were made based on the findings of the study:

The implication of the main objective of the study implies that, Should the Central Bank of Ghana embark on contractionary monetary policy, when means reducing money supply in the economy will eventually results in a reduction in the performance of the stock market. Hence the study recommends that Expansionary Monetary policy will be a better option to be carried out to improve upon the stock market performance in Ghana since increasing money supply will enable Ghanaian to purchase share and stock on the Ghanaian stock market.

The study also reveals that foreign direct investment had a positive relationship with stock market performance in Ghana. The study recommend that, the monetary authority should work effectively be able sta- 
bilize the macroeconomic indicators such as inflation and exchange rate to help attract foreign investment in Ghana. Thus Government and private partnership should ensure effective management of the exchange rate fluctuations in Ghana to boost stock market performance.

The study also discovered that there is a negative relationship between monetary policy and stock market performance in both the long-run and short-run. The study therefore recommends that the monetary authorities should engineer an effective mechanism for stabilizing and reducing the monetary policy over a long period of time.

\section{References}

Alfaro, L., \& Chauvin, J. (2012). Foreign direct investment, finance, and economic development (Chapter for the Encyclopedia of International Economics and Global Trade, Forthcoming, Available at SSRN:). https://ssrn.com/ abstract $=2908440$.

Antwi-Asare, T., Cooke, E. F., Twerefou, D. K. Cockburn, J., Fofana, I., \& Tiberti, L. (2010). Simulating the impact of the global economic crisis and policy responses on children in ghana (Working Paper No. 2010-16). PEP-MPIA doi:10.2139/ssrn.1807302

Baafi Antwi, J. (2010). Capital based macroeconomic model and 100 percent reserve system, free banking system and bfh system: A comparism among latvia, lithuania, kazakhstan, and kyrgyzstan. (MPRA Paper No. 22935). Munich Personal RePEc Archive. https://mpra.ub.uni-muenchen .de/22935/.

Ben Naceur, S., \& Kandil, M. (2009). The impact of capital requirements on banks' cost of intermediation and performance: The case of egypt. Journal of Economics and Business, 61(1), 7089. doi:10.1016/j.jeconbus.2007.12.001

Cassola, N., \& Morana, C. (2004). Monetary policy and the stock market in the euro area. Journal of Policy Modeling, 26(3), 387-399. doi:10.1016/j.jpolmod.2004.03.012

Durham, J. B. (2001). The effect of monetary policy on monthly and quarterly stock market returns (Working Paper). doi:10.2139/ssrn.293102

Fosu, A., \& Aryeetey, E. (2008). Economic growth in ghana: 1960-2000. In R. Kanbur \& E. Aryeetey (Eds.), The economy of ghana: Analytical perspectives on stability, growth, and poverty (pp. 68-94). Accra: Woeli Publishing.

Ghatak, S., \& Siddiki, J. U. (2001). The use of the ARDL approach in estimating virtual exchange rates in India. Journal of Applied statistics, 28(5), 573-583. doi:10.1080/02664760120047906

Harvey, C. R., Liu, Y., \& Zhu, H. (2015, 10). $\ldots$ and the Cross-Section of Expected Returns. The Review of Financial Studies, 29(1), 5-68. doi:10.1093/rfs/hhv059

Hayford, M. D., \& Malliaris, A. G. (2004). Monetary policy and the u.s. stock market. Economic Inquiry, 42(3), 387-401. doi:10.1093/ei/cbh068

Ioannidis, C., \& Kontonikas, A. (2006). Monetary Policy and the Stock Market: Some international evidence (Working Paper). https://core.ac.uk/ download/pdf/6627695.pdf.

Ioannidis, C., \& Kontonikas, A. (2008). The impact of monetary policy on stock prices. Journal of Policy Modeling, 30(1), 33-53. doi:10.1016/j.jpolmod.2007.06.015

Keynes, J. M. (1936). Econometric analysis. London: Macmillan.

M., F. (1988). Money and the stock market. Journal of Political Economy, 96(2), 221-245. doi:10.1086/261534

Muktadir-Al-Mukit, D. (2013). An econometric analysis of the impact of monetary policy on stock market performance in bangladesh. World Review of Business Research, 3(3), 16-29. https://www.researchgate.net/profile/Dewan _Mukit/publication/270450600_An_Econometric _Analysis_of_the_Impact_of_Monetary_Policy _on_Stock_Market_Performance_in_Bangladesh/ links/54aaadce0cf25c4c472f467c.pdf.

Mwasya, G. N. (2016). The effect of the central bank rate on stock market performance at the nairobi securities exchange (Doctoral Dissertation). Nairobi: University of Nairobi. http:// erepository.uonbi.ac.ke/handle/11295/99668.

Nemaorani, T. (2012). Impact of monetary policy on stock prices: Evidence from botswana (Unpublished BA Economics Project). University of Botswana.

Ngigi, M. (2008). Structure, conduct and performance of commodity markets in South Sudan: Linkages food security (Study Report). FAO. http://www.fao.org/fileadmin/user_upload/ sifsia/docs/South_Sudan_SCP_study\%20report_1 .pdf.

Nwakoby, C. I. N., \& Alajekwu, U. B. (2016). Effect of monetary policy on nigerian stock market performance. International Journal of Scientific Research and Management, 4(9), 4530-4442. https://www.researchgate.net/ profile/Nwakoby_Clement_Ndukaife_Ikechukwu/ publication/308527441_Effect_of_Monetary _Policy_on_Nigerian_Stock_Market_Performance/ links/57e660b608ae9227da9d3a46/Effect-of -Monetary-Policy-on-Nigerian-Stock-Market -Performance.pdf.

Okpara, G. C. (2010). Monetary policy and stock market returns: Evidence from nigeria. Journal of Economics, 1(1), 13-21. doi:10.1080/09765239.2010.11884920 
Osuagwu, E. S. (2009). The effect of monetary policy on stock market performance in nigeria Nigeria Journal of Securities and Finance, (NSE), 14(2). https://www.researchgate.net/ profile/Eze_Osuagwu/publication/290980649 _THE_EFFECT_OF_MONETARY_POLICY _ON_STOCK_MARKET_PERFORMANCE_IN _NIGERIA/links/5c196befa6fdccfc70586e1e/ THE-EFFECT-OF-MONETARY-POLICY -ON-STOCK-MARKET-PERFORMANCE-IN -NIGERIA.pdf.

Pesaran, M. H., \& Pesaran, B. (1997). Working with microfit 4.0. Cambridge: Camfit Data Ltd.

Pesaran, M. H., Shin, Y., \& Smith, R. J. (2001). Bounds testing approaches to the analysis of level relationships. Journal of Applied Econometrics, 16(3), 289-326. doi:10.1002/jae.616

Pesaran, M. H., Shin, Y., \& Smith, R. P. (1999). Pooled mean group estimation of dynamic heterogeneous panels. Journal of the American Statistical Association, 94(446), 621-634. doi:10.1080/01621459.1999.10474156

Qayyum, A., \& Anwar, S. (2011). Impact of Monetary Policy on the Volatility of Stock Market in Pakistan (MPRA Paper). Munich Personal RePEc Archive. https://mpra.ub.uni-muenchen .de/31188/.

Raza, A., Ahmed, Z., Ahmed, M., \& Ahmed, T. (2012). The Role of FDI on Stock Market Development: The Case of Pakistan. Journal of Economics and Behavioral Studies, 4(1), 26-33. doi:10.22610/jebs.v4i1.299

Saleem, F., Zafar, L., \& Rafique, B. (2012). Long run relationship between inflation and stock return: evidence from Pakistan. Academic Research International, 4(2), 407-415. http://www.savap.org.pk/journals/ARInt./ Vol.4(2)/2013(4.2-42).pdf.

Sunday, O. A. (2013). Impact of monetary policy on Nigerian economic growth. Prime Journal of Social Science (PJSS), 2(2), 195199. http://primejournal.org/PJSS/abstracts/ 2013/feb/Okoro.htm.

Tang, T. C. (2006). New evidence on export expansion, economic growth and causality in China. Applied Economics Letters, 13(12), 901803. doi:10.1080/13504850500425303

Taufian, G. I. (2018). The influence of residual income (ri), return on equity (roe), return on assets (roa), earnings per share (eps) and beta stock toward the stock price in sub-sector construction (Unpublished BA Thesis). Yogyakarta State University.

Thorbecke, W. (1997). On stock market returns and monetary policy. The Journal of Finance, 52(2), 635-654. doi:10.1111/j.15406261.1997.tb04816.x

UNCTAD. (2018). Global FDI Flows Slipped Further in 2017 (Investment Trends Monitor No. 28).

Yao, T., Yu, T., Zhang, T., \& Chen, S. (2011). Asset growth and stock returns: Evidence from asian financial markets. Pacific-
Basin Finance Journal, 19(1), 115-139. doi:10.1016/j.pacfin.2010.09.004

Yoshino, N., Taghizadeh Hesary, F., Hassanzadeh, A., \& Prasetyo, A. D. (2014). Response of stock markets to monetary policy: An Asian stock market perspective (ADBI Working Paper). doi:10.2139/ssrn.2492046 


\section{Appendices}

Plot of cumulative sum of recursive residuals and plot of cumulative sum of squares of recursive residuals are given in Figure A1 and Figure A2, respectively.

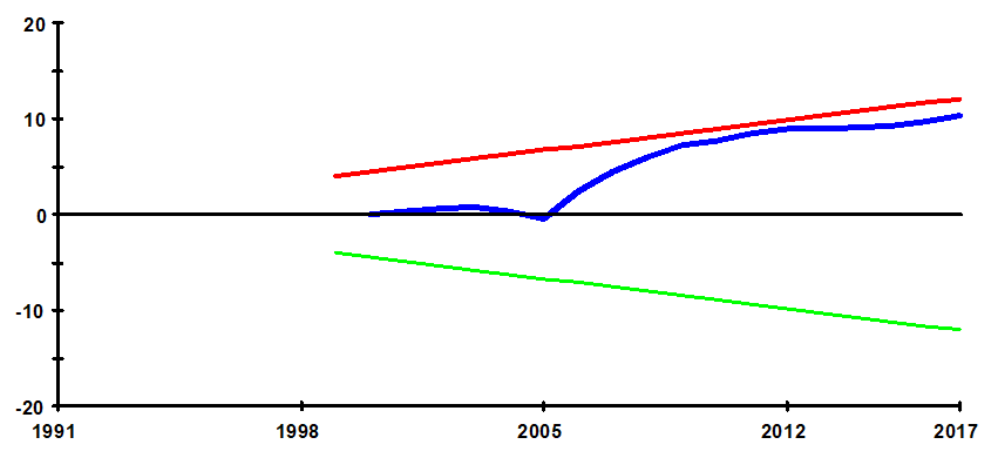

Figure A1: Plot of cumulative sum of recursive residuals

Notes: The straight lines represents critical bounds at $5 \%$ significance level.

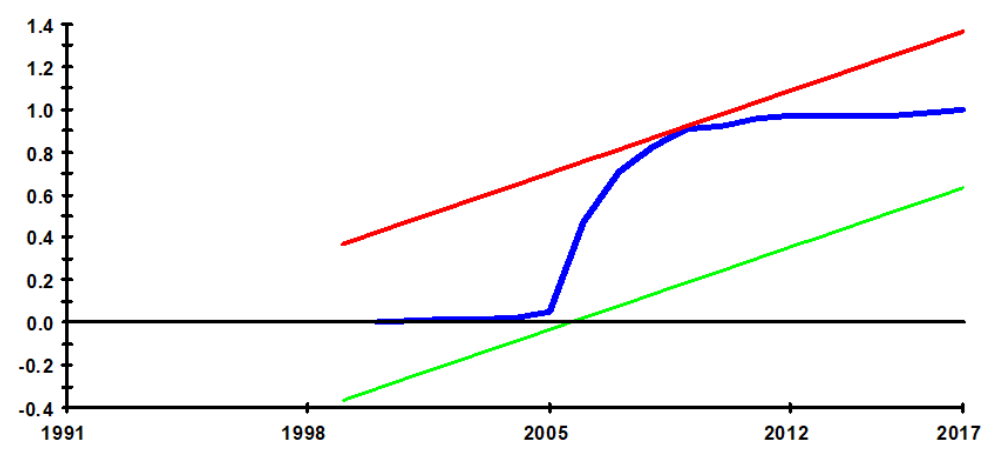

Figure A2: Plot of cumulative sum of squares of recursive residuals

Notes: The straight lines represents critical bounds at $5 \%$ significance level 